\title{
Foreword
}

\section{David Collins}

Death is the cure of all diseases

Thomas Browne (1605-82)

By convention the foreword to an academic collection such as this should do at least three things: first, it should welcome the reader. Secondly, it should set the scene for the contributions that follow and, in so doing it should establish the significance of the undertaking. Finally the foreword (insofar as it is generally penned by an individual who, through their personal endeavors in the field, has acquired a reputation as a key contributor to the subject under consideration) should offer insights which bring gravitas to the proceedings.

I am grateful to Professor Örtenblad for the invitation to write this foreword. And yet I feel that I should offer my colleague (and you) an apology because, if I am honest, I feel able to fulfill only the first two requirements that convention demands! Doubtful of my position therefore I will, with your indulgence, use this opportunity to offer personal reflections on my own attempts to make sense of 'management panaceas'. These reflections, I hope, will serve to welcome you to this collection and to frame the various contributions that constitute this useful and timely text. Furthermore I hope that my comments might encourage you to incorporate the book's key themes and its primary lessons into your daily practice. To this end I will commence with reflections on the origins and nature of the cure-all, or panacea. I will then proceed to consider (a) the manner in which business panaceas have been represented and (b) the prospects for what might be termed a 're-presentation' of business fads.

\section{PANACEA (PANÁKEIA)}

The term 'panacea' entered the English language around 1548, when it was said to take the form of an 'all-healing herb'. The dictionary compilers note, however, that this herb has been 'variously identified'. This tendency to announce panaceas that are short-lived and inconsistent with practices, only recently announced as 'the answer', frames Thomas Browne's skepticism (above) and is, as we shall see, central to the term's current disparagement in the field of business and management. 
Panacea (Panákeia) was the Greek goddess of healing. The daughter of Asclepius (the god of medicine) and Epione (the goddess of pain relief), Panákeia was one of four sisters, each dedicated to their father's craft. Given that the body which produces 'management panaceas' management's gurus (Huczynski 1993) - is almost exclusively male, one might be forgiven for harboring the suspicion that the term is either wilfully ironic or simply catachrestic. Yet since no lesser authority than Dickens $(1843 \text { [1922] })^{1}$ warns us against tampering with familiar phrases I will neither pursue nor persist with this argument but will, instead, invite consideration of what it is we rail against whenever we denounce something as merely a panacea.

A panacea is, as we have already established, a cure-all. In modern medicine its lexical equivalents would include such things as 'elixirs', 'patent medicine' and 'snake-oil'. Panaceas are sold by 'quacks'. The purchasers of such preparations are, consequently, taken to be either gullible, desperate or both! In the field of business and management the term panacea is not, typically, utilized by those who produce management knowledge. The men who produce such knowledge-products are, I would venture, shrewd enough to understand that any manager worth his/her salt would neither support nor recommend an innovation that had been marketed as a simple cure-all. Indeed it is clear to me that the gurus understand the modern consumer only too well and are, therefore, wise enough to recognize that a medical panacea which cured cancer but had only a moderate impact upon halitosis and, frankly, disappointing outcomes on dandruff and dry skin would be met by a Twitter storm of derision. Thus the term 'management panacea' should be understood as a labeling device. Furthermore we should be clear that this device has been applied by a group, separate from the cadre of management gurus, which has nonetheless emerged to consider the wit and wisdom of their more venerated colleagues. This grouping, which I have dubbed the 'guru industry' (Collins 2000) offers reflections on guru theory (Huczynski 1993) and, as we shall see, runs the gamut from hagiology through apology to apoplexy (Collins 2003).

The hagiologists of the 'guru industry' tend to concede that key management innovations such as Total Quality Management (TQM) and Business Process Re-engineering (BPR) may precipitate resistance to change and may be, consequently, difficult to implement. But the hagiologists would never dream of suggesting that such innovations represent the quackery of snake-oil. Indeed the hagiologists, as we might expect, argue that the gurus are worthy of veneration because they provide templates for action, which are both novel and productive (see for example Kennedy 1996, 1998). The apologists for guru theory, on the other hand, tend to suggest that managers have been let down, or have been carried 
away by, rhetorical constructions, which suggest that guru theory offers tools and/or constructs that will simply fix the contemporary problems of managing. Countering such assertions the apologists of the guru industry seek to place a tempered appreciation of key innovations within a framework that recognizes that the ideas and practices of guru theorizing need to be adapted if they are to be embedded within contemporary organizations. Finally those angered by guru theory tend to suggest that such frameworks need to be located in a broader social-historical context and would argue (for example) that management panaceas are destructive because the gurus ride as the vanguard of a neo-liberal attack on the social institutions of the workplace and the broader polity which - in the name of service, quality and empowerment - places each of us on the start line for a 'race to the bottom'. Those who would have us reject innovations such as BPR, therefore, often employ terms such as 'fads' and 'fashions' to signal their conviction that the idea (or practice) under review is stupid, without foundation, and yet, somehow, dangerous. The problem being, of course, that both the hagiologists and those who have produced more critical assessments of business panaceas offer analyses of guru theorizing that (a) ignore the complex lexical history of faddism and (b) tend to downplay the extent to which panaceas may be translated to reflect local conditions. Let us pause, therefore, to consider the etymology of 'fads' before proceeding to consider the manner in which such innovations are represented in business practice.

\section{THE ETYMOLOGY OF FADS}

The Oxford Library of Words and Phrases (Volume III) suggests that 'fad' is an 18th-century word; a shortened version of 'fiddle-faddle' which is, in turn, a 16th-century term meaning 'trifling talk or action'. The roots of the term are French (fadaise) and ultimately Latin (fatuus). References to this word in texts from the 1880s use the modern and familiar sense of the term, and so, suggest that a fad is 'a fashion, a craze'. As Furnham (2004, p.1) puts it, fads 'go in one era and out the other'. Yet earlier usage of the word suggests that 'fads' may be sustained and may lead to processes and outcomes that are (if only on the margins) productive and useful. Thus Collins (2012) suggests that, in the 1830s, the term 'fad' was synonymous with 'a hobby' and might well be regarded as a 'pet project' or 'crotchet' that could sustain and enlighten. Indeed Moorhouse's (1988) reflections on the constitution of 'industrial sociology' make room for the speculation that the pejorative associations that came to adhere to 'fads' some time between the 1830 s and the 1880 s simply demonstrate the triumph of the 
Victorian preoccupation with paid employment as the primary source of purpose, identity and spiritual well-being. This suggestion, that Victorian sensibilities have had a crucial influence on our appreciation of 'fads' and 'faddism' is, of course, speculative. What does seem clear, however, is that in a rush to promote their preferred agendas the various constituents of the 'guru industry' have failed, properly, to consider their central analytical concept and have consequently tended to assume that the term 'fad' has a stable meaning which is commonly accepted and understood. The problem being, as we shall see, is that this presumption cannot survive its first contact with practice.

\section{FADS IN PRACTICE}

Cole (1999) has produced a useful and distinctive account of the practical problems associated with managing 'fads'. His analysis suggests that the term 'fad' is inappropriate to the analysis of business innovation. Offering an in-depth, longitudinal analysis of the American experience of quality management, Cole begins by observing that: 'Management fads appear inherently hostile to both effective imitative and learning activities. After all, the term $\mathrm{fad}$ connotes transience. Webster's Third International Dictionary defines fad as "a pursuit or interest followed usually widely, but briefly and capriciously, with exaggerated zeal and devotion" (Cole 1999, p. 14). Consequently he warns us that: 'Fads are seen as costly distractions that keep managers from concentrating on running the business' (ibid. p. 14). Yet he protests that this is a misapprehension. Studying the processes necessary to the pursuit of TQM, Cole (1999) argues that there is a pattern and a context to organizational innovation. Thus he notes that, in the US, interest in Quality was more pronounced in those organizations that were exposed to foreign competition - such as the chemicals, car and electronics industries. Furthermore he suggests that fears over the growth of public liability law-suits in relation to product defects also helped to convert managers to quality management. Yet Cole observes that, despite these inducements, conversion to quality matters was slow in the US. Indeed he argues that the early quality innovations produced patchy and often contradictory results. Now at this point the apoplectic end of the 'guru industry' spectrum would tend to suggest that such disappointing experiences demonstrate, only too painfully, that fads are alien to, and inconsistent with, good management. But Cole is not swayed by this. Positioning himself somewhere between the apologists and those who have been driven to apoplexy by business fads, he warns us that, in the context of the workplace, imitation (so-called) is rather difficult 
and represents a creative challenge for all concerned. The false-starts, disappointments and reversals experienced by the pioneers of quality management - what more casual commentaries would tend to dismiss as the consequences of fad-based imitation - Cole suggests might usefully be regarded as the inevitable outcomes of an imaginative process of experimentation and translation.

Looking more closely at the organizational processes that translate ideals into situated forms of innovation, Cole observes that there has been a tendency to overestimate the pace at which genuinely novel ideas are generated by organizational consultants. Taking issue with those such as Pascale (1990) and Gill and Whittle (1993) who have suggested that 'panaceas' are (a) short-lived and (b) act to reverse previous innovations, Cole argues that succeeding business ideas do not wipe out earlier movements. Consequently he suggests that business fads cannot be viewed as being, either, genuinely novel or, obviously, inconsistent with what went before. Indeed he protests that the quality movement provided key, experimental and experiential building blocks for Business Process Reengineering (BPR). Far from being a transient fad, therefore, Cole argues that the Quality movement (fad) actually signals a long-term commitment to learning and experimentation in US organizations.

Brindle and Stearns (2001) have also sought to prompt reflection on the assumptions (and refrains) which underpin the contemporary analysis of managerial panaceas. They argue that innovations such as TQM and BPR acquire an audience and a marketplace, not because managers are easily duped (see Collins 2000 for a critique of Hilmer and Donaldson 1996) but because they help organizational actors to do things. Listing these productive outcomes, Brindle and Stearns suggest that 'fads' may help to provide a sense of common identity. Highlighting the sectional nature of organizations, therefore, Brindle and Stearns suggest that organizational innovations are productive insofar as they allow managers to engage in public demonstrations of activity and energy. In other words 'fads' are an index of that most prized of managerial assets: vision! Pursuing this ideal, Brindle and Stearns suggest that 'fads' promote organizational isomorphism and in so doing, may reduce investor and customer anxiety. Thus the authors argue that fads 'permit conformity under the guise of novelty and independence, and all the while give voice and identity' (Brindle and Stearns 2001, p. 7) to managerial aspirations. Recognizing the complexity of organizational life, therefore, Brindle and Stearns suggest that managers may be forgiven for pursuing ideas that armchair commentators regard as mere fiddle-faddle. However, they show no such mercy to Harvard Business Review (HBR). Indeed they suggest that a shift in editorial policy in the 1970s served to diminish practitioner understanding of the essential 
complexity of organized life. There were, Brindle and Stearns (2001, p. 60) tell us, 'three main tacks' associated with this course change:

1. 'a significant shift away from an historical, philosophical grounding toward a decidedly ahistorical bent' (pp. 60-61);

2. a retreat from those perspectives which attempted to place the consideration of management in a social and economic context;

3. the development of a self-help ethos which meant that 'speed [in action] and [analytical] simplification became virtues' (p. 63).

Brindle and Stearns do insist, however, that faddism can be controlled. Noting that the simplistic celebration of 'action' and 'practice' fostered by HBR has closed minds to the virtues of broader forms of theoretical and historical reflection, they suggest that the academy must step forward and must promote a curriculum that can rescue managers from the clutches of business faddism. Doubts, however, persist as to the efficacy of the approach preferred by Brindle and Stearns (2001). Thus the authors acknowledge the sectional nature of social organization but choose to place themselves in a privileged position. In this respect Brindle and Stearns appear to channel the spirit of Humpty Dumpty ${ }^{2}$ insofar as they suggest that the key question, when fads are scrutinized, is not the position of the gurus per se, but which guru is to be recognized as master!

Cole's approach is, of course, rather different: it looks to practitioners for salvation. Yet in so doing, it creates its own problems. Indeed Cole's celebration of the innovation and experimentation which, within organizations, has allowed practitioners to translate TQM from a simple 'fad' into organizational forms that are useful and productive seems to point towards a Panglossian ${ }^{3}$ optimism which ignores, or seriously underestimates, the broader (unaccounted) costs and losses that accrue when managerial innovations are pursued.

Acknowledging the limitations (and the merits) of these contrasting approaches I conclude by suggesting a few operating principles that might be useful to recall when considering 'management panaceas' and the contributions which constitute the remainder of this text.

1. Dump the term fad. Labeling and disparaging the ideas and practices of others as just fads is, as we have seen, seldom merited particularly when the practices required to embed the necessary changes are actually considered (for a more detailed account see Collins 2001, 2012). In this regard contemporary usage of the term 'fad' signals, to me, little more than an unthinking adherence to a bleak sensibility, a Victorian 
midwinter of the soul, which would banish creativity, imagination and innovation from public debate.

2. Recognize the virtue of innovation and by all means applaud the creativity associated with change. But do not romanticize these processes.

Innovation and competition must imply costs and losses. Given this, does the author employ a unitary or a more pluralistic account of organizational life? Does s/he assume that our corporations are damaged by fads as Hilmer and Donaldson (1996) do? Or does s/he operate with an analytical frame that recognizes the sectional nature of organizations and the mixture of costs and benefits associated with innovation? In addition it is worth asking: Does the contribution portray managers as 'cultural dopes' or does it acknowledge the internal, emotional and political drivers that might predispose us to seek, either, comfort or personal advantage from the pursuit of organizational innovations?

3. Do not assume that managers or indeed others within the organization are the passive recipients of change. Such assumptions generally culminate in an inconsistent approach, one which couches a thoughtless form of anti-management within an over-arching unitary framework (see Collins 2000).

So ask: Does the commentary treat practitioners as passive recipients of ideas or does it acknowledge the complexities of consumption and the active nature of these processes?

4. Recognize that as either practitioner or scholar you have a serious and personal interest in ideas, practices, innovations and forms of expression that are 'cutting-edge'.

So ask: Does the author write in a reflexive fashion? Have they acknowledged their own interest in all things fashionable?

5. Do not presume that as a serious scholar or professional practitioner you may safely ignore 'fads'. The key innovations that have been labeled as 'fads' operate in our schools, in our hospitals and throughout our governmental structures. These innovations are not transient. The changes invoked in their name are not about to go away. The genie is - well and truly - out of the bottle.

So ask: Does the work have any policy implications? And perhaps more significantly, does the analytical framework generate guidance for future conduct that extends beyond trading one set of (practitioner) gurus for another set of (academic) luminaries?

And finally...

6. Consider making gender (and other aspects of identity) an explicit analytical component of your approach. At present the literature on 
fads and fashions is deeply 'gendered' insofar as it tends to project the understanding that workers are all alike (and male).

So ask: what does the contribution say to and about the experience of women, both within and beyond the workplace?

\author{
David Collins \\ Professor in Management at the University of Hull
}

\title{
NOTES
}

1. Introducing A Christmas Carol, Dickens pauses to consider the phrase, 'dead as a doornail', which he has just used to describe the state of Jacob Marley. He suggests that it would, surely, be wrong to consider this piece of ironmongery as the most mortal form of nail. Yet he refuses to pursue the challenge which he suggests may be merited. Justifying his position he avers: 'the wisdom of our ancestors is in the similie; and my unhallowed hands shall not disturb it, or the Country's done for. You will therefore permit me to repeat, emphatically, that Marley was dead as a door-nail' (Dickens 1843 [1922], p. 1).

2. Humpty Dumpty appears in Lewis Carroll's Through the Looking Glass (1872 [2010]) where he discusses semantics and pragmatics with Alice. The text reproduced below appeared in a, now famous, legal judgment and is often utilized by scholars of language and linguistics. Here I draw in particular upon the closing words voiced by Humpty Dumpty. My suggestion is that much academic scholarship on fads and fashions appears to discuss the merits of guru theory but in truth boils down to a contest between gurus, the issue at hand being, as Humpty Dumpty suggests, which is to be master:

'I don't know what you mean by “glory”,' Alice said.

Humpty Dumpty smiled contemptuously. 'Of course you don't - till I tell you. I meant "there's a nice knock-down argument for you!"”

'But "glory" doesn't mean "a nice knock-down argument",' Alice objected.

'When I use a word,' Humpty Dumpty said, in a rather scornful tone, 'it means just what I want it to mean - neither more nor less.'

'The question is,' said Alice, 'whether you can make words mean so many different things.'

'The question is,' said Humpty Dumpty, 'which is to be master - that's all.' (ibid. p. 72)

3. Dr Pangloss appears in Voltaire's famous comic novel: Candide (Voltaire 1759 [2005]). In this text Pangloss acts as tutor to the eponymous Candide. 'Leibnizian optimism', an unremittingly up-beat personal philosophy, is central to the curriculum of Dr Pangloss. As the novel concludes, however, Candide is obliged to temper this optimistic philosophy in the face of experience.

\section{REFERENCES}

Brindle, Margaret C. and Peter N. Stearns (2001), Facing Up to Management Faddism: A New Look at an Old Force, Westport, CT: Quorum Books.

Carroll, Lewis (1872 [2010]), Through the Looking Glass, London: Collins Classics.

Cole, Robert E. (1999), Managing Quality Fads: How American Business Learned to Play the Quality Game, Oxford: Oxford University Press. 


\section{xxxiv Handbook of research on management ideas and panaceas}

Collins, David (2000), Management Fads and Buzzwords: Critical-Practical Perspectives, London: Routledge.

Collins, D. (2001), 'The fad motif in management scholarship', Employee Relations, 23 (1), 26-37.

Collins, D. (2003), 'Guest editor's introduction: re-imagining change', Tamara: Journal of Critical Postmodern Organization Science, 2 (4), iv-xi.

Collins, David (2012), 'Management fashion', in David Boje, Bernard Burnes and John Hassard (eds), The Routledge Companion to Organizational Change, Abingdon: Taylor and Francis Routledge, pp. 310-31.

Dickens, Charles (1843 [1922]), A Christmas Carol, London: Miller, Son and Company.

Furnham, Adrian (2004), Management and Myths: Challenging Business Fads, Fallacies and Fashions, Basingstoke: Palgrave Macmillan.

Gill, J. and S. Whittle (1993), 'Management by panacea: accounting for transience', Journal of Management Studies, 30 (2), 281-95.

Hilmer, Fred G. and Lex Donaldson (1996), Management Redeemed: Debunking the Fads that Undermine Our Corporations, New York: Free Press.

Huczynski, Andrzej A. (1993), Management Gurus: What Makes Them and How to Become One, London: Routledge.

Kennedy, Carol (1996), Managing with the Gurus: Top Level Guidance on 20 Management Techniques, London: Century Books.

Kennedy, Carol (1998), Guide to the Management Gurus: Shortcuts to the Leading Ideas of Leading Management Thinkers, London: Century Books.

Moorhouse, Herbert F. (1988), Driving Ambitions: A Social Analysis of the American Hot Rod Enthusiasm, Manchester: Manchester University Press.

Pascale, Richard T. (1990), Managing on the Edge: How the Smartest Companies Use Conflict to Stay Ahead, London: Simon and Schuster.

Voltaire, François (1759 [2005]), Candide (trans. Theo Cuffe), London: Penguin Books. 